\title{
Synthesis, Spectroscopic, and DFT Studies of Some Platinum-Pyrazine Carboxamide Derivatives
}

\author{
Ramadan M. Ramadan, ${ }^{1}$ Ahmad K. Abu Al-Nasr, ${ }^{2}$ and Samir M. El-Medani ${ }^{3}$ \\ ${ }^{1}$ Chemistry Department, Faculty of Science, Ain Shams University, Cairo 11566, Egypt \\ ${ }^{2}$ Chemistry Department, Faculty of Science, Taibah University, Almadinah Almunawrah 42353, Saudi Arabia \\ ${ }^{3}$ Chemistry Department, Faculty of Science, Fayoum University, Fayoum 63514, Egypt \\ Address correspondence to Ramadan M. Ramadan,r_m_ramadan@yahoo.com
}

Received 31 May 2018; Accepted 21 October 2018

Copyright (C) 2018 Ramadan M. Ramadan et al. This is an open access article distributed under the terms of the Creative Commons Attribution License, which permits unrestricted use, distribution, and reproduction in any medium, provided the original work is properly cited.

\begin{abstract}
Binary and ternary platinum(II) and platinum(IV) complexes were synthesized using heterocyclic ligands with nitrogen and oxygen donor atoms (2-pyrazinecarboxamide, pyridine, and bipyridine). The complexes were characterized by the analytical and spectroscopic tools such as elemental analysis, mass spectrometry, IR, and ${ }^{1} \mathrm{H}$ NMR spectroscopy. The complexes showed different structural arrangements. The thermogravimetry analysis of some selected complexes were also investigated. Theoretical calculations based on accurate density functional theory (DFT) approximations were established to verify the optimized structures of the pyrazine carboxamide ligand and two complexes. The global chemical reactivity descriptors were estimated from the energy of the HOMO and LUMO orbitals.
\end{abstract}

Keywords pyrazine derivatives; platinum complexes; spectroscopic studies; DFT studies

\section{Introduction}

Transition metal-based complexes represent an important class of chemotherapeutics, widely used in the clinic as antitumor and antiviral agents. They offer potential advantages over the more common organic-based drugs. The more established antitumor metallodrugs, routinely used in treatment of cancer patients, are cis-platin [cisdiamminedichloroplatinum(II)] and its analogues [1]. However, their drug resistance and side effects have limited their clinical use. Vast efforts are committed to develop novel transition metal-based derivatives, such as platinum(II), platinum(IV) and ruthenium complexes, which might overcome the disadvantages of cis-platin and have higher antitumor activity as well $[2,3,4,5]$. Considerable amount of interest has focused on the use of pyridine platinum(II) complexes as mimics of cis-platin [6]. These studies have shown that the use of planar ligands, such as the substituted pyridines in platinum(II) complexes, can reduce the rate of deactivation by sulfhydryl groups without interfering with DNA binding, which is considered to be the mode of action of $c i s$-platin $[6,7,8]$.

Our interest in the synthesis of various transition metal complexes with heterocyclic ligands that have appropriate


Bpy

Scheme 1: Structure of ligands.

biological activities and show promising applications as antitumor drugs $[3,4]$ has prompted us to synthesize and investigate other platinum(II) and platinum(IV) complexes of these ligands (Scheme 1). In this article, we report the synthesis, and characterization of some $\mathrm{Pt}(\mathrm{II})$ and $\mathrm{Pt}(\mathrm{IV})$ complexes with nitrogen heterocyclic ligands. Density functional theory (DFT) calculations are also carried out to explore the optimized structures of the ligand and some complexes.

\section{Experimental methods}

\subsection{Materials and instruments}

Chloride salts of platinum(II) and platinum(IV), in addition to the heterocyclic nitrogen donor ligands, were purchased from Aldrich. All the solvents were of analytical reagent grade and were purified using standard methods. IR measurements ( $\mathrm{KBr}$ pellets) were carried out on a Unicam-Mattson 1000 FT-IR spectrometer. 
Table 1: Color, yield, elemental analysis, and mass spectrometry data of the platinum complexes.

\begin{tabular}{|c|c|c|c|c|c|c|c|c|c|}
\hline \multirow{2}{*}{ Complex } & \multirow{2}{*}{ Molecular formula } & \multirow{2}{*}{ Color } & \multirow{2}{*}{ Yield (\%) } & \multicolumn{4}{|c|}{ Elemental analysis, found (calc.) } & \multicolumn{2}{|c|}{ Mass spectrometry } \\
\hline & & & & $\% \mathrm{C}$ & $\% \mathrm{H}$ & $\% \mathrm{~N}$ & $\% \mathrm{Cl}$ & M.W. & $\mathrm{m} / \mathrm{z}$ \\
\hline$\left[\mathrm{Pt}(\mathrm{PCA})_{2}\right] \mathrm{Cl}_{2}(1)$ & $\mathrm{C}_{10} \mathrm{H}_{10} \mathrm{~N}_{6} \mathrm{O}_{2} \mathrm{Cl}_{2} \mathrm{Pt}$ & Brown & 85 & $\begin{array}{l}23.48 \\
(23.45)\end{array}$ & $\begin{array}{l}1.86 \\
(1.97)\end{array}$ & $\begin{array}{l}16.49 \\
(16.41)\end{array}$ & $\begin{array}{l}13.90 \\
(13.84)\end{array}$ & 512.22 & $\begin{array}{l}442\left[\mathrm{P}-\mathrm{Cl}_{2}\right]^{+} \\
319\left[\mathrm{P}-\mathrm{PCA}-\mathrm{Cl}_{2}\right]^{+}\end{array}$ \\
\hline$\left[\mathrm{Pt}(\mathrm{PCA})(\mathrm{Py})_{2}\right] \mathrm{Cl}_{2}$ & $\mathrm{C}_{15} \mathrm{H}_{15} \mathrm{~N}_{5} \mathrm{OCl}_{2} \mathrm{Pt}$ & Brown & 66 & $\begin{array}{l}32.96 \\
(32.92)\end{array}$ & $\begin{array}{l}2.73 \\
(2.76)\end{array}$ & $\begin{array}{l}12.83 \\
(12.80)\end{array}$ & $\begin{array}{l}13.02 \\
(12.96)\end{array}$ & 547.31 & $\begin{array}{l}477\left[\mathrm{P}-\mathrm{Cl}_{2}\right]^{+}, \\
397\left[\mathrm{P}-\mathrm{Py}-\mathrm{Cl}_{2}\right]^{+}, \\
354\left[\mathrm{P}-\mathrm{PCA}-\mathrm{Cl}_{2}\right]^{+}, \\
318\left[\mathrm{P}-2 \mathrm{Py}-\mathrm{Cl}_{2}\right]^{+}\end{array}$ \\
\hline$[\mathrm{Pt}(\mathrm{PCA})(\mathrm{Bpy})] \mathrm{Cl}_{2}$ & $\mathrm{C}_{15} \mathrm{H}_{13} \mathrm{~N}_{5} \mathrm{OCl}_{2} \mathrm{Pt}$ & Pale brown & 69 & $\begin{array}{l}33.09 \\
(33.04)\end{array}$ & $\begin{array}{l}2.35 \\
(2.40)\end{array}$ & $\begin{array}{l}12.80 \\
(12.84)\end{array}$ & $\begin{array}{l}13.08 \\
(13.00)\end{array}$ & 545.30 & $\begin{array}{l}475\left[\mathrm{P}-\mathrm{Cl}_{2}\right]^{+}, \\
352\left[\mathrm{P}-\mathrm{PCA}-\mathrm{Cl}_{2}\right]^{+}, \\
319\left[\mathrm{P}-\mathrm{Bpy}-\mathrm{Cl}_{2}\right]^{+}\end{array}$ \\
\hline$\left[\mathrm{Pt}(\mathrm{PCA})(\mathrm{Py})_{2} \mathrm{Cl}_{2}\right] \mathrm{Cl}_{2}(4)$ & $\mathrm{C}_{15} \mathrm{H}_{15} \mathrm{~N}_{5} \mathrm{OCl}_{4} \mathrm{Pt}$ & Brown & 54 & $\begin{array}{l}29.18 \\
(29.14)\end{array}$ & $\begin{array}{l}2.42 \\
(2.45)\end{array}$ & $\begin{array}{l}11.30 \\
(11.33)\end{array}$ & $\begin{array}{l}22.98 \\
(22.94)\end{array}$ & 618.22 & $\begin{array}{l}548\left[\mathrm{P}-\mathrm{Cl}_{2}\right]^{+}, \\
469\left[\mathrm{P}-\mathrm{Py}-\mathrm{Cl}_{2}\right]^{+}, \\
425\left[\mathrm{P}-\mathrm{PCA}-\mathrm{Cl}_{2}\right]^{+}, \\
275\left[\mathrm{P}-\mathrm{Cl}_{2}\right]_{2}^{+}\end{array}$ \\
\hline$\left[\mathrm{Pt}(\mathrm{PCA})\left(\mathrm{Bpy} \mathrm{Cl}_{2}\right] \mathrm{Cl}_{2}(5)\right.$ & $\mathrm{C}_{15} \mathrm{H}_{13} \mathrm{~N}_{5} \mathrm{OCl}_{4} \mathrm{Pt}$ & Brown & 62 & $\begin{array}{l}29.29 \\
(29.24)\end{array}$ & $\begin{array}{l}2.15 \\
(2.13)\end{array}$ & $\begin{array}{l}11.35 \\
(11.39)\end{array}$ & $\begin{array}{l}22.96 \\
(23.01)\end{array}$ & 616.20 & $\begin{array}{l}423\left[\mathrm{P}-\mathrm{PCA}-\mathrm{Cl}_{2}\right]^{+}, \\
390\left[\mathrm{P}-\mathrm{Bpy}-\mathrm{Cl}_{2}\right]^{+}, \\
273\left[\mathrm{P}-\mathrm{Cl}_{2}\right]_{2}^{+}\end{array}$ \\
\hline
\end{tabular}

NMR measurements were performed on a SpectrospinBruker $300 \mathrm{MHz}$ spectrometer. Thermogravimetric analysis measurements were carried out $\left(\mathrm{N}_{2}\right.$ atmosphere) at a heating rate of $10^{\circ} \mathrm{C} / \mathrm{min}$ using a Shimadzu DT-50 thermal instrument. Elemental analyses were measured using Perkin-Elmer $2400 \mathrm{CHN}$ elemental analyzer. Mass spectrometry measurements of the solid complexes (70 eV, EI) were carried out on a Finnigan MAT SSQ 7000 spectrometer. Conductivity measurements were made on a YSI conductivity meter model 32 . Samples of concentration ca. $1 \times 10^{-3}-1 \times 10^{-6} \mathrm{M}$ in DMSO were used for the measurements.

\subsection{Synthesis of complexes}

\subsubsection{Synthesis of $\left[\mathrm{Pt}(\mathrm{PCA})_{2}\right] \mathrm{Cl}_{2}$ complex}

A solution of pyrazine carboxamide (PCA) ligand $(0.5 \mathrm{mmol})$ in a minimum amount of ethanol is added dropwise with constant stirring to a $0.5 \mathrm{mmol}$ solution of $\left[\mathrm{PtCl}_{4}\right]^{2-}$. The mixture was heated for half an hour at $60{ }^{\circ} \mathrm{C}$, at which the complex was precipitated. The resultant residue was filtered off and washed with hot petroleum ether. The obtained residue was recrystallized from hot ethanol. The isolated fine crystals were left to dry under vacuum for several hours.

\subsubsection{Synthesis of ternary Pt(II) and Pt(IV) complexes}

Equimolar amounts of the PCA ligand with either pyridine or bipyridine $(0.5 \mathrm{mmol}$ from each) were mixed and dissolved in the minimum amount of ethanol. The solution was added dropwise with constant stirring to an aqueous solution of $\left[\mathrm{PtCl}_{4}\right]^{2-}$ or $\left[\mathrm{PtCl}_{6}\right] 2-(0.5 \mathrm{mmol})$. The mixture was heated to $70^{\circ} \mathrm{C}$ for $1 \mathrm{~h}$. The solvent was evaporated, and the solid residue was washed with hot petroleum ether and then recrystallized from hot ethanol. The isolated fine crystals were left to dry under vacuum for several hours.

\subsection{Computational details}

All the calculations were performed using the hybrid DFT method B3LYP as implemented in the Gaussian 09 software package. The geometries were optimized using the standard double-zeta plus polarization basis set 6-31G (d,p) for PCA ligand atoms and effective core potential basis set LANL2DZ for platinum complexes. The purpose of the quantum mechanics calculations validates the proposed $3 \mathrm{D}$ structure of the obtained complexes so as to to find out key factors for their reactivities.

\section{Results and discussion}

\subsection{Spectroscopic and analytical studies}

Some platinum(II) and platinum(IV) complexes were isolated from the reactions of 2-pyrazinecarboxamide (PCA) and a secondary ligand (either pyridine, Py, or bipyridine, Bpy). The chemical composition of these complexes was as follows: $\left[\mathrm{Pt}(\mathrm{PCA})_{2}\right] \mathrm{Cl}_{2}(1),\left[\mathrm{Pt}(\mathrm{PCA})(\mathrm{Py})_{2}\right] \mathrm{Cl}_{2}$ (2), $[\mathrm{Pt}(\mathrm{PCA})(\mathrm{Bpy})] \mathrm{Cl}_{2}$ (3), $\left[\mathrm{Pt}(\mathrm{PCA})\left(\mathrm{Py}_{2} \mathrm{Cl}_{2}\right] \mathrm{Cl}_{2}\right.$ (4), $\left[\mathrm{Pt}(\mathrm{PCA})(\mathrm{Bpy}) \mathrm{Cl}_{2}\right] \mathrm{Cl}_{2}(5)$. The structures of the complexes were characterized using elemental analysis, mass, IR, ${ }^{1} \mathrm{H}$ NMR spectrometry as well as thermogravimetry (TG) technique. The ionized and total chloride contents of the complexes were determined potentiometrically using silver ion electrode. Table 1 gives the color, yield, elemental analysis, and mass spectrometry data of the complexes. The fragmentation patterns in the mass spectra of the complexes along with the thermal analysis as well as the elemental analysis data revealed the correctness of the suggested molecular formulas. The electrical molar conductance in DMSO at room temperature for all complexes exhibited high molar conductance $(112.5-136.4 \mu \mathrm{S})$ due to their electrolytic characteristics and the number of ionized chloride ions.

The IR spectra of the complexes displayed characteristic bands of ligands, $v(\mathrm{NH}), v(\mathrm{C}=\mathrm{N})$, and $v(\mathrm{C}=\mathrm{O})$, with 
Table 2: IR and NMR data of the PCA and the platinum complexes.

\begin{tabular}{|c|c|c|c|c|}
\hline \multirow{2}{*}{ Compound } & \multicolumn{3}{|c|}{ IR data $\left(\mathrm{cm}^{-1}\right)$} & \multirow{2}{*}{${ }^{1} \mathrm{H}$ NMR data (ppm) } \\
\hline & $v(\mathrm{NH})$ & $v(\mathrm{C}=\mathrm{N})$ & $v(\mathrm{C}=\mathrm{O})$ & \\
\hline \multirow[t]{4}{*}{ PCA } & $3,413(\mathrm{~s})$ & $1,610(\mathrm{~s})$ & $1,714(\mathrm{~s})$ & $9.28(\mathrm{~d}, 1 \mathrm{~Hz}, \mathrm{Pz}-\mathrm{CH})$ \\
\hline & $3,290(\mathrm{~m})$ & $1,580(\mathrm{~m})$ & & $8.95(\mathrm{~d}, 8 \mathrm{~Hz}, \mathrm{Pz}-\mathrm{CH})$ \\
\hline & $3,210(\mathrm{sh})$ & & & $8.81(\mathrm{dd}, 8,1 \mathrm{~Hz}, \mathrm{Pz}-\mathrm{CH})$ \\
\hline & $3,163(\mathrm{~s})$ & & & $8.42(\mathrm{bs}, \mathrm{NH}), 8.02(\mathrm{bs}, \mathrm{NH})$ \\
\hline \multirow[t]{4}{*}[\mathrm{Pt}(\mathrm{PCA})_{2}]{$\mathrm{Cl}_{2}(1)$} & $3,278(\mathrm{~m})$ & $1,692(\mathrm{sh})$ & $1,705(\mathrm{~s})$ & $9.17(\mathrm{~d}, 1 \mathrm{~Hz}, \mathrm{Pz}-\mathrm{CH})$ \\
\hline & $3,189(\mathrm{~m})$ & & & $8.88(\mathrm{~d}, 8 \mathrm{~Hz}, \mathrm{Pz}-\mathrm{CH})$ \\
\hline & $3,103(\mathrm{~m})$ & & & $8.76(\mathrm{dd}, 8,1 \mathrm{~Hz}, \mathrm{Pz}-\mathrm{CH})$ \\
\hline & $3,074(\mathrm{~m})$ & & & $8.28(\mathrm{bs}, \mathrm{NH}), 7.87(\mathrm{bs}, \mathrm{NH})$ \\
\hline \multirow[t]{4}{*}[\mathrm{Pt}(\mathrm{PCA})(\mathrm{Py})_{2}]{$\mathrm{Cl}_{2}(2)$} & $3,277(\mathrm{~m})$ & $1,655(\mathrm{~m})$ & $1,706(\mathrm{vs})$ & $9.18(\mathrm{~d}, 1 \mathrm{~Hz}, \mathrm{Pz}-\mathrm{CH}), 8.91$ (m, Py-CH), \\
\hline & $3,187(\mathrm{~m})$ & $1,593(\mathrm{~m})$ & & $8.86(\mathrm{~d}, 8 \mathrm{~Hz}, \mathrm{Pz}-\mathrm{CH}), 8.72(\mathrm{dd}, 9,1 \mathrm{~Hz}, \mathrm{Pz}-\mathrm{CH})$ \\
\hline & $3,101(\mathrm{~m})$ & & & 8.25 (bs, NH), 8.04 (m, Py-CH), 7.90 (bs, NH), \\
\hline & $3,072(\mathrm{~m})$ & & & 7.65 (m, Py-CH), 7.56 (m, Py-CH) \\
\hline \multirow[t]{4}{*}[\mathrm{Pt}(\mathrm{PCA})(\mathrm{Bpy})]{$\mathrm{Cl}_{2}(3)$} & $3,280(\mathrm{~m})$ & $1,650(\mathrm{sh})$ & $1,706(\mathrm{~s})$ & $9.52(\mathrm{~d}, 1 \mathrm{~Hz}, \mathrm{Pz}-\mathrm{CH}), 9.19$ (d, 8 Hz, Pz-CH), \\
\hline & $3,191(\mathrm{~m})$ & $1,595(\mathrm{~m})$ & & $8.84(\mathrm{~m}, \mathrm{Py}-\mathrm{CH}), 8.70(\mathrm{dd}, 7,1 \mathrm{~Hz}, \mathrm{Pz}-\mathrm{CH})$ \\
\hline & $3,103(\mathrm{~m})$ & & & 8.58 (bs, NH), 8.44 (m, Py-CH), \\
\hline & $3,074(\mathrm{~m})$ & & & $8.32(\mathrm{bs}, \mathrm{NH}), 7.84(\mathrm{~m}, \mathrm{Py}-\mathrm{CH})$ \\
\hline \multirow[t]{4}{*}[\mathrm{Pt}(\mathrm{PCA})(\mathrm{Py})_{2}\mathrm{Cl}_{2}]{$\mathrm{Cl}_{2}(4)$} & $3,266(\mathrm{~m})$ & $1,650(\mathrm{~m})$ & $1,712(\mathrm{~s})$ & $9.23(\mathrm{~d}, 1 \mathrm{~Hz}, \mathrm{Pz}-\mathrm{CH}), 8.95$ (m, Py-CH), \\
\hline & $3,188(\mathrm{~m})$ & $1,592(\mathrm{~m})$ & & $8.86(\mathrm{~d}, 8 \mathrm{~Hz}, \mathrm{Pz}-\mathrm{CH}), 8.76(\mathrm{dd}, 9,1 \mathrm{~Hz}, \mathrm{Pz}-\mathrm{CH})$ \\
\hline & $3,100(\mathrm{~m})$ & & & 8.24 (bs, NH), 8.09 (m, Py-CH), 7.93 (bs, NH), \\
\hline & $3,068(\mathrm{~m})$ & & & 7.71 (m, Py-CH), 7.58 (m, Py-CH) \\
\hline \multirow[t]{4}{*}[\mathrm{Pt}(\mathrm{PCA})(\mathrm{Bpy})\mathrm{Cl}_{2}]{$\mathrm{Cl}_{2}(5)$} & $3,265(\mathrm{~m})$ & $1,644(\mathrm{~m})$ & $1,700(\mathrm{~s})$ & $9.52(\mathrm{~d}, 1 \mathrm{~Hz}, \mathrm{Pz}-\mathrm{CH}), 9.21$ (d, $8 \mathrm{~Hz}, \mathrm{Pz}-\mathrm{CH})$, \\
\hline & $3,192(\mathrm{~m})$ & $1,590(\mathrm{~m})$ & & 8.87 (m, Py-CH), 8.71 (dd, 7, 1 Hz, Pz-CH), \\
\hline & $3,103(\mathrm{~m})$ & & & 8.53 (bs, NH), $8.44(\mathrm{~m}, \mathrm{Py}-\mathrm{CH})$, \\
\hline & $3,064(\mathrm{~m})$ & & & $8.32(\mathrm{bs}, \mathrm{NH}), 7.84(\mathrm{~m}, \mathrm{Py}-\mathrm{CH})$ \\
\hline
\end{tabular}

corresponding shifts due to complex formation (Table 2) [3, $9,10]$. The stretching frequencies of $\mathrm{C}=\mathrm{N}$ bonds in the IR spectra of complexes were shifted to higher frequencies, while the $v(\mathrm{NH})$ in complexes containing 2-pyrazinecarboxamide ligand were shifted to lower frequencies relative to those of free ligand $[11,12,13]$. The $v(\mathrm{C}=\mathrm{O})$ frequencies were shifted to lower frequencies confirming participation of the carbonyl group of the PCA in coordination of their complexes [10]. Furthermore, all the spectra showed nonligand bands in the range $651-419 \mathrm{~cm}^{-1}$ corresponding to the stretching frequencies of $\mathrm{M}-\mathrm{O}$ and $\mathrm{M}-\mathrm{N}$ bonds $[10,11,14,15]$.

The ${ }^{1} \mathrm{H}$ NMR spectra of the complexes gave more insight on their structure. All the spectra performed signals due to protons of the coordinated ligands. The spectra of the ternary complexes showed sets of signals due to the $\mathrm{NH}$, pyridyl, and pyrazine moieties with corresponding shifts (Table 2) [13,16]. From the spectroscopic data, it can be concluded that the 2-pyrazinecarboxamide and bipyridine acted as bidentate through nitrogen and oxygen donor atoms, while the pyridine ligand coordinated from the pyridyl nitrogen (Scheme 2).

\subsection{Thermal analysis}

To examine the structure and thermal stability of the platinum complexes, thermal studies were carried out

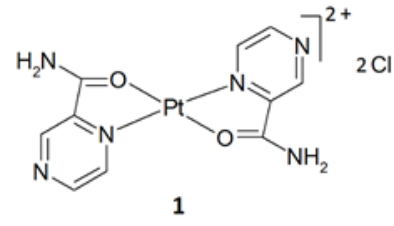<smiles>Nc1cncc[n+]1P(n1cccc1)n1cccc1</smiles><smiles></smiles><smiles></smiles><smiles></smiles>

Scheme 2: The proposed structure of the complexes.

using thermogravimetry (TG) technique [17]. The TG data of the complexes are tabulated in Table 3. The TG curve of $\left[\mathrm{Pt}(\mathrm{PCA})(\mathrm{Py})_{2}\right] \mathrm{Cl}_{2}$ (2) complex exhibited two 
Table 3: Thermal analysis data for the platinum complexes.

\begin{tabular}{cccccccc}
\hline Molecular formula & Molecular weight & $\begin{array}{l}\text { Decomposition } \\
\text { temperature }\left({ }^{\circ} \mathrm{C}\right)\end{array}$ & Weight loss $(\%)$ & $\begin{array}{l}\text { Mass loss/mole } \\
\text { found (Calc.) }\end{array}$ & Eliminated species & $\begin{array}{l}\text { Solid decomposition } \\
\text { residue }(\%)\end{array}$ \\
\hline$\left[\mathrm{Pt}(\mathrm{PCA})(\mathrm{Py})_{2}\right] \mathrm{Cl}_{2}(2)$ & 547.41 & $77-406$ & 34.65 & $189.68(190.13)$ & $\mathrm{C}_{7} \mathrm{H}_{6}+\mathrm{N}_{2}+\mathrm{Cl}_{2}$ & 38.53 \\
& & $407-649$ & 26.63 & $145.77(149.16)$ & $\mathrm{C}_{8} \mathrm{H}_{9}+\mathrm{N}_{2}+0.5 \mathrm{O}_{2}$ & $(\mathrm{Pt})$ & 38.95 \\
& 545.29 & $50-277$ & 7.70 & $42.00(42.00)$ & $\mathrm{CO}+0.5 \mathrm{~N}_{2}$ & \\
{$[\mathrm{Pt}(\mathrm{PCA})(\mathrm{Bpy})] \mathrm{Cl}_{2}(3)$} & & $279-413$ & 24.30 & $132.32(143.04)$ & $\mathrm{CH}_{4}+2 \mathrm{~N}_{2}+\mathrm{Cl}_{2}$ & \\
& & $414-565$ & 29.00 & $158.15(153.20)$ & $\mathrm{C}_{12} \mathrm{H}_{9}$ & $\left(\mathrm{PtC}_{2}\right)$ \\
\hline
\end{tabular}

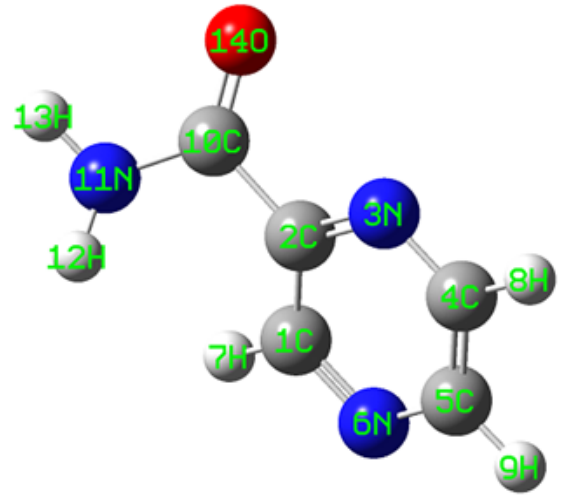

PCA

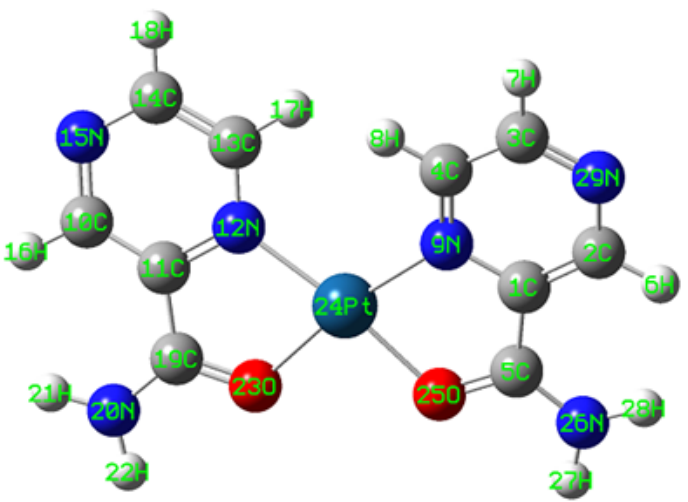

1

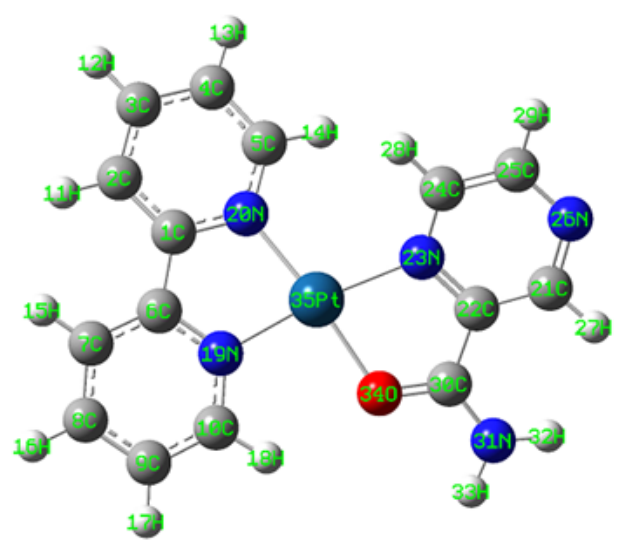

3

Figure 1: The optimized structures of PCA and platinum complexes.

well-defined decomposition steps within the temperature range $77-649^{\circ} \mathrm{C}$. The first decomposition step occurred at temperature range $77-406^{\circ} \mathrm{C}$ and was corresponding probably due to the loss of $\mathrm{C}_{7} \mathrm{H}_{6}+\mathrm{N}_{2}+\mathrm{Cl}_{2}$ species. The second decomposition step included the removal of $\mathrm{C}_{8} \mathrm{H}_{9}+\mathrm{N}_{2} \mathrm{O}$ with a net weight loss of $26.63 \%$ leaving metallic platinum as a residue.

The thermogravimetric plot of the $[\mathrm{Pt}(\mathrm{PCA})(\mathrm{Bpy})] \mathrm{Cl}_{2}$ (3) complex showed three well-defined decomposition steps within the temperature range $50-565^{\circ} \mathrm{C}$. The first decomposition step corresponded to the loss of $\mathrm{CO}+0.5 \mathrm{~N}_{2}$ moieties with a net weight loss of $7.70 \%$. The second decomposition step within the temperature range $279-413^{\circ} \mathrm{C}$ (net weight loss of $24.30 \%$ ) was assigned to the elimination of $\mathrm{CH}_{4}+$
$2 \mathrm{~N}_{2}+\mathrm{Cl}_{2}$ species. The third decomposition step within the temperature range $414-565^{\circ} \mathrm{C}$ gave mass loss of $29.00 \%$ (Calc. $28.09 \%$ ) assigned to the elimination of $\mathrm{C}_{12} \mathrm{H}_{9}$ moiety to give finally $\mathrm{PtC}_{2}$ species as a residue.

According the thermogravimetric patterns of the investigated complexes, the thermal stability increases in the order $[\mathrm{Pt}(\mathrm{PCA})(\mathrm{Bpy})] \mathrm{Cl}_{2}<\left[\mathrm{Pt}(\mathrm{PCA})(\mathrm{Py})_{2}\right] \mathrm{Cl}_{2}$.

3.3. The stereochemistry and chemical reactivity prediction The stereochemistry of PCA and two of the platinum complexes were investigated by the hybrid DFT method. The optimized structures of these compounds are given in Figure 1. We will focus first on the structure of the PCA with a total steric energy $=5.34 \mathrm{kcal} / \mathrm{mol}$. The dihedral angle 

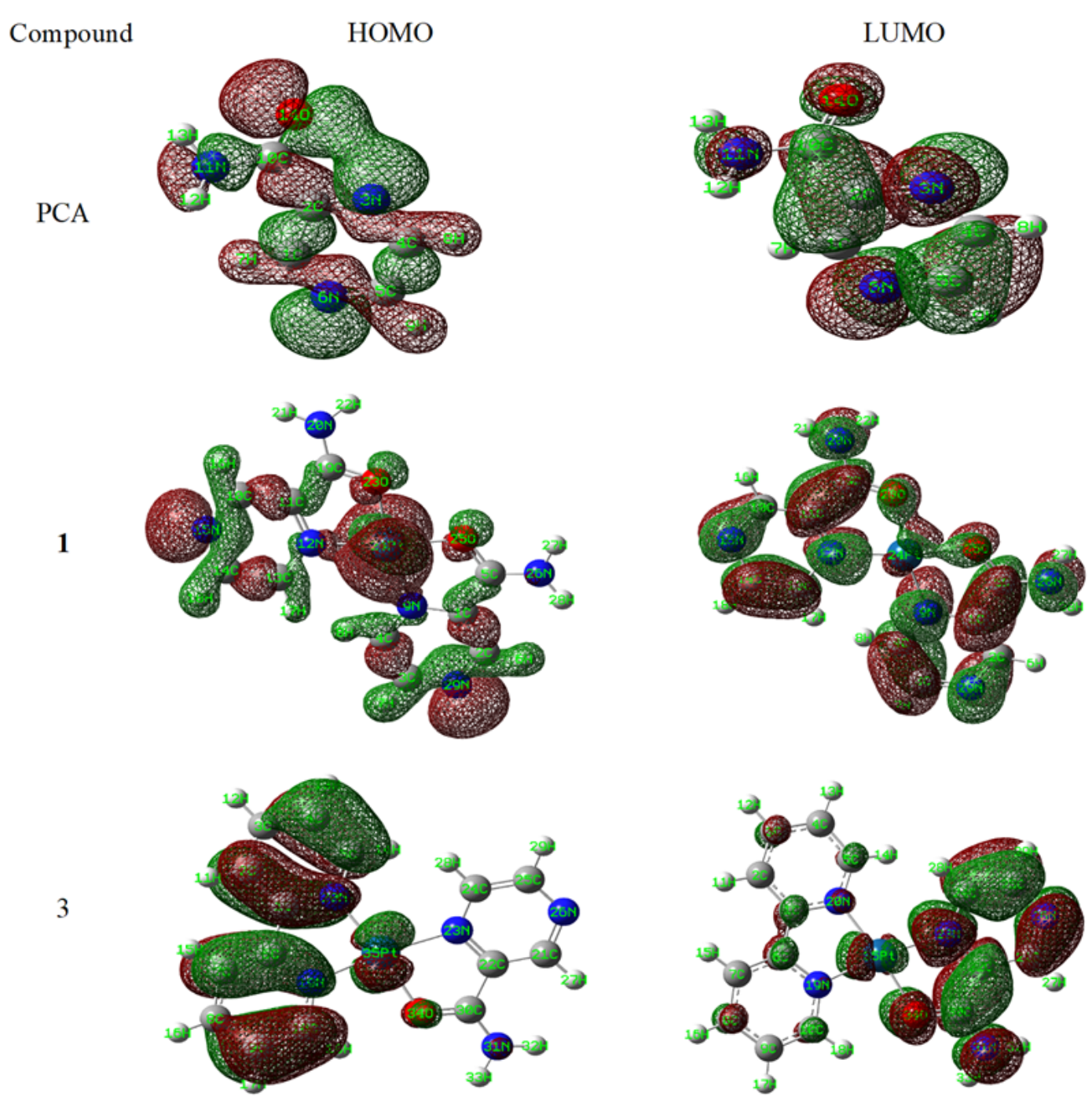

Figure 2: The frontier molecular orbitals of PCA and the platinum complexes.

between the two planes including $\mathrm{C}_{1}-\mathrm{C}_{2}-\mathrm{C}_{10}-\mathrm{N}_{11}$ was found to be $33.6^{\circ}$, which means that the molecule is almost planar. The bond lengths between $\mathrm{C}_{10}-\mathrm{O}_{14}$ and $\mathrm{C}_{10}-\mathrm{N}_{11}$, Figure 1, were $1.22 \AA$ and $1.38 \AA$, respectively. These values are in the expected range of $\mathrm{C}=\mathrm{O}$ and $\mathrm{C}-\mathrm{N}[18,19]$. On the other hand, the bond angle of $\mathrm{C}_{2}-\mathrm{C}_{10}-\mathrm{N}_{11}$ is found to be smaller $\left(114.64^{\circ}\right)$ than that of $\mathrm{C}_{2}-\mathrm{C}_{10}-\mathrm{O}_{14}, 122.2^{\circ}$. This could retain to the repulsion of the two lone pairs on the oxygen atom.

The energetically stable model of $\left[\mathrm{Pt}(\mathrm{PCA})_{2}\right]^{2+}(1)$ species with a distorted square planar geometry was found to have about $77.51 \mathrm{kcal} / \mathrm{mol}$, which is consistent with the spectroscopic findings (Scheme 1). The bond angles $\mathrm{N}_{9}-\mathrm{Pt}_{24}-\mathrm{O}_{25}, \mathrm{~N}_{12}-\mathrm{Pt}_{24}-\mathrm{O}_{23}$, and $\mathrm{O}_{23}-\mathrm{Pt}_{24}-\mathrm{O}_{25}$ were found to be $79.0^{\circ}, 79.0^{\circ}$, and $92.0^{\circ}$, respectively. Again, the larger value of the latter bond could be due to the oxygen lone pair repulsion. On the other hand, the bond angles of $\mathrm{N}_{12}-\mathrm{Pt}_{24}-\mathrm{O}_{25}$ and $\mathrm{N}_{9}-\mathrm{Pt}_{24}-\mathrm{O}_{23}$ are close to linear $\left(170.1^{\circ}\right)$. The $\mathrm{Pt}-\mathrm{N}(2.06 \AA)$ bond length was found to be slightly longer than that of $\mathrm{Pt}-\mathrm{O}(2.03 \AA)$. In case of the $[\mathrm{Pt}(\mathrm{PCA})(\mathrm{Bpy})]^{2+}$ (3) complex, the optimized structure has a minimization energy of $79.80 \mathrm{kcal} / \mathrm{mol}$ with a distorted square planar structure (Figure 1). The bond lengths and bond angles were found to be comparable with those of the complex (1). Selected values are $\mathrm{N}_{19}-\mathrm{Pt}_{35}(2.02 \AA)$, $\mathrm{O}_{34}-\mathrm{Pt}_{35} \quad(2.07 \AA), \mathrm{C}_{30}-\mathrm{O}_{34} \quad(1.30 \AA), \mathrm{N}_{19}-\mathrm{Pt}_{35}-\mathrm{N}_{20}$ $\left(79.9^{\circ}\right), \quad \mathrm{N}_{23}-\mathrm{Pt}_{35}-\mathrm{O}_{34}\left(78.2^{\circ}\right)$, and $\mathrm{N}_{19}-\mathrm{Pt}_{35}-\mathrm{N}_{23}$ $\left(170.4^{\circ}\right)$, respectively.

The global chemical reactivity parameters including HOMO, LUMO, energy gap $(\Delta \mathrm{E})$, electronegativity $(X)$, chemical potential $(V)$, electron affinity $(A)$, ionization potential $(I)$, chemical hardness $(\eta)$, chemical softness $(S)$, and electrophilicity $(\omega)$ of the reported compounds are given in Table 4 [20,21,22,23]. The frontier molecular orbital energies were estimated using DFT method (B3LYP) and illustrated in Figure 2. The HOMO orbital energy 
Table 4: The global chemical reactivity descriptors for the PCA and the platinum complexes.

\begin{tabular}{cccc}
\hline Parameter & PCA & 1 & 3 \\
\hline DM (Debye) & 3.39 & 0.20 & 0.68 \\
HOMO $(\mathrm{eV})$ & -6.80 & -14.37 & -13.60 \\
LUMO $(\mathrm{eV})$ & -1.82 & -10.47 & -9.94 \\
$\Delta \mathrm{E}(\mathrm{eV})$ & 4.98 & 3.90 & 3.66 \\
$X(\mathrm{eV})$ & 4.31 & 12.42 & 11.77 \\
$V(\mathrm{eV})$ & -4.31 & -12.42 & -11.77 \\
$A(\mathrm{eV})$ & 1.82 & 10.47 & 9.94 \\
$I(\mathrm{eV})$ & 6.80 & 14.37 & 13.60 \\
$\eta(\mathrm{eV})$ & 2.49 & 1.95 & 1.83 \\
$S(\mathrm{eV})$ & 1.24 & 0.98 & 0.92 \\
$\omega(\mathrm{eV})$ & 3.73 & 39.50 & 37.84 \\
\hline
\end{tabular}

represents the electron donating ability, while the LUMO orbital energy characterizes the electron withdrawing ability. The energy gap between HOMO and LUMO shows the molecular chemical stability; it is a critical parameter for determining molecular electrical transport properties. Smaller energy gap reflects the easiness of the charge transfer (CT), and the polarization which occurs within the molecule [24]. Therefore, the order of increasing reactivity of the reported complexes is $[\mathrm{Pt}(\mathrm{PCA})(\mathrm{Bpy})]^{2+}>$ $\left[\mathrm{Pt}(\mathrm{PCA})_{2}\right]^{2+}$. Also, the electronegativity parameter is a reflection for the electrostatic potential, where the electron partially transferred from one of lower electronegativity to another of higher electronegativity [24]. The results showed that the order of decreasing $X$ is $\left[\mathrm{Pt}(\mathrm{PCA})_{2}\right]^{2+}>[\mathrm{Pt}(\mathrm{PCA})(\mathrm{Bpy})]^{2+}$. On the other hand, the results of small chemical hardness values for the reported derivatives reflect the ability of charge transfer within the molecule. The order of increasing the charge transfer within the molecule is $\left[\mathrm{Pt}(\mathrm{PCA})_{2}\right]^{2+}<[\mathrm{Pt}(\mathrm{PCA})(\mathrm{Bpy})]^{2+}$.

\section{Conclusion}

Spectroscopic studies of some binary and ternary $\mathrm{Pt}(\mathrm{II})$ and $\mathrm{Pt}(\mathrm{IV})$ complexes of heterocyclic ligands showed variable molecular and structural features. Optimized structures of the ligand and some platinum complexes using DFT calculations revealed the correctness of the proposed structures.

Acknowledgments The authors declare that they have no conflict of interest.

\section{References}

[1] E. Wong and C. M. Giandomenico, Current status of platinumbased antitumor drugs, Chem Rev, 99 (1999), 2451-2466.

[2] M. J. Clarke, Ruthenium metallopharmaceuticals, Coord Chem Rev, 236 (2003), 209-233.

[3] R. M. Ramadan, A. K. Abu Al-Nasr, and A. F. Noureldeen, Synthesis, spectroscopic studies, antimicrobial activities and antitumor of a new monodentate $V$-shaped Schiff base and its transition metal complexes, Spectrochim Acta A Mol Biomol Spectrosc, 132 (2014), 417-422.
[4] R. M. Ramadan and N. S. Al-Raddady, Spectroscopic studies, biological activity, and cytotoxicity of some binary and ternary palladium and platinum complexes of certain heterocyclic ligands, Synth React Inorg Met-Org Nano-Met Chem, 45 (2015), 1183-1190.

[5] W. M. Motswainyana and P. A. Ajibade, Anticancer activities of mononuclear ruthenium (II) coordination complexes, Adv Chem, 2015 (2015), 1-21.

[6] J. Holford, F. Raynaud, B. A. Murrer, K. Grimaldi, J. A. Hartley, M. Abrams, et al., Chemical, biochemical and pharmacological activity of the novel sterically hindered platinum co-ordination complex, cis-[amminedichloro(2-methylpyridine)] platinum(II) (AMD473), Anticancer Drug Des, 13 (1998), 1-18.

[7] M. Hay, ZD-0473 Johnson Matthey plc, Curr. Opin. Oncol. Endocr. Metab. Invest. Drugs, 1 (1999), 443-447.

[8] T. V. Segapelo, I. A. Guzei, L. C. Spencer, W. E. Van Zyl, and J. Darkwa, (Pyrazolylmethyl) pyridine platinum (II) and gold (III) complexes: Synthesis, structures and evaluation as anticancer agents, Inorg Chim Acta, 362 (2009), 3314-3324.

[9] R. M. Silverstein, G. C. Bassler, and T. C. Morrill, Spectrometric Identification of Organic Compounds, John Wiley \& Sons, New York, 4th ed., 1981.

[10] K. Nakamoto, Infrared and Raman Spectra of Inorganic and Coordination Compounds, John Wiley \& Sons, New York, 1986.

[11] S. M. El-Medani, O. A. M. Ali, H. A. Mohamed, and R. M. Ramadan, Spectroscopic, thermal and X-ray crystal structure studies of some bis-(pyrazine-2-carboxylato) nickel (II) complexes, J Coord Chem, 58 (2005), 1429-1437.

[12] R. M. Ramadan, S. M. El-Medani, O. A. M. Ali, and H. A. Mohamed, Spectroscopic and thermal studies of some palladium complexes with certain heterocyclic nitrogen ligands, J Coord Chem, 57 (2004), 373-379.

[13] S. M. El-Medani, T. A. Youssef, and R. M. Ramadan, Spectroscopic and X-ray crystal structure of 2-aminobenzimidazoletrinitrobenzene charge-transfer and 2-aminobenzimidazolepicric acid ion-pair derivatives, J Mol Struct, 644 (2003), 77-87.

[14] O. A. M. Ali, L. H. Abdel-Rahman, and R. M. Ramadan, Ruthenium carbonyl derivatives of $\mathrm{N}$-salicylidene-2-hydroxyaniline, $\mathrm{J}$ Coord Chem, 60 (2007), 2335-2342.

[15] M. A. Taher, S. E. Jarelnabbi, A. G. M. Al-Sehemi, S. M. ElMedani, and R. M. Ramadan, Synthesis and spectroscopic studies of some new metal carbonyl derivatives of 1-(2-pyridylazo)-2naphthol, J Coord Chem, 62 (2009), 1293-1301.

[16] C. S. Hawes and P. E. Kruger, Synthesis and characterisation of dinuclear $\mathrm{Co}(\mathrm{II}), \mathrm{Ni}(\mathrm{II})$ and $\mathrm{Cu}(\mathrm{II})$ unsaturated helical complexes from a novel dipyridyl-bispyrazole ligand, Polyhedron, 52 (2013), 255-260.

[17] T. Hatakeyama and Z. Liu, Handbook of Thermal Analysis, John Wiley \& Sons, Chichester, UK, 1998.

[18] J. Demaison and A. G. Császár, Equilibrium CO bond lengths, J Mol Struct, 1023 (2012), 7-14.

[19] F. H. Allen, O. Kennard, D. G. Watson, L. Brammer, A. G. Orpen, and R. Taylor, Tables of bond lengths determined by X-ray and neutron diffraction. Part 1. Bond lengths in organic compounds, J Chem Soc Perkin 2, 1987 (1987), S1-S19.

[20] N. Raja, R. Ramesh, and Y. Liu, Paramagnetic ruthenium (III) complexes bearing O,O chelating ligands: Synthesis, spectra, molecular structure and electron transfer properties, Polyhedron, 31 (2012), 196-201.

[21] S. Chandra and L. K. Gupta, Electronic, EPR, magnetic and mass spectral studies of mono and homo-binuclear $\mathrm{Co}(\mathrm{II})$ and $\mathrm{Cu}(\mathrm{II})$ complexes with a novel macrocyclic ligand, Spectrochim Acta A Mol Biomol Spectrosc, 62 (2005), 1102-1106.

[22] B. J. Hathaway and D. E. Billing, The electronic properties and stereochemistry of mono-nuclear complexes of the copper (II) ion, Coord Chem Rev, 5 (1970), 143-207. 
[23] D. Kivelson and R. Neiman, ESR studies on the bonding in copper complexes, J Chem Phys, 35 (1961), 149-155.

[24] A. A. Abdel Aziz, F. M. Elantabli, H. Moustafa, and S. M. ElMedani, Spectroscopic, DNA binding ability, biological activity, DFT calculations and non linear optical properties (NLO) of novel $\mathrm{Co}(\mathrm{II}), \mathrm{Cu}(\mathrm{II}), \mathrm{Zn}(\mathrm{II}), \mathrm{Cd}(\mathrm{II})$ and $\mathrm{Hg}(\mathrm{II})$ complexes with ONS schiff base, J Mol Struct, 1141 (2017), 563-576. 